\title{
ТЕОРЕТИЧНІ ПІДХОДИ В ПРОЦЕСІ РЕАЛІЗАЦЇ̈ ДЕРЖАВНОГО УПРАВЛІННЯ ФІЗИЧНОЮ КУЛЬТУРОЮ І СПОРТОМ
}

Нікітенко С. В., канд. іст., наук, доцент, Херсонський державний аграрний університет, м. Херсон, Україна

На основі аналізу існуючих наукових підходів, у статті досліджується сутність механізмів державного управління фізичною культурою та спортом в Україні. Зокрема розглянуті актуальні наукові концепти до визначення поняття «фізична культура і спорт» та «механізм державного управління», «програмно-цільове управління», «програмно-цільовий метод управління», «програмно-цілььвий приниип управління», «програмно-цілььовий підхід».

Акиентовано увагу щзо в нашій країні ефективним способом по вирішенню значимих проблем стало напрацювання цільових комплексних програм, щзо вимагають суттєвих фінансових витрат, концентрації зусиль різних міністерств і відомств. У иій частині сочіально-економічної сфери за роки незалежності накопичено суттєве теоретичне осмислення і практичний досвід.

Головними завданнями щзо постали перед автором изе визначитися із суб' 'ктністю законотворчої інічіативи; осмислити відмову від парадигми самодостатності законодавчої діяльності; визначитися з підходами до теоретичних засад сочіологічних досліджень становища фізичної культури і спорту; усвідомити необхідність $i$ важливість запровадження контролю щзодо законодавчої роботи владних суб'єктів з боку громадськості тощзо.

Як специфічний вид життєдіяльності управління покликане реалізуватися за допомогою здійснення послідовних управлінських дій, які класифікуються як «функиї̈ управління. Стаття акиентує увагу на необхідності визначення сутності відносно нового специфічного механізму державного управління, який виникає в резуль- 
таті запровадження процесу децентралізащії влади в Украӥні. На основі проведеного дослідження робляться висновки щзодо розуміння сутності механізму державного управління фізичною культурою та спортом в Україні.

Ключові слова: фізична культура і спорт, механізми державного управління.

Постановка проблеми у загальному виді. У різних галузях знань до теперішнього часу ще немає єдиного загальноприйнятого визначення поняття «фізична культура і спорт». Така ситуація обумовлена цілою низкою чинників. Окрпім того, необхідно враховувати, що фізична культура і спорт складають два значних сегменти: спорт вищих досягнень (професійний спорт), а також фізична культура і спорт, яким громадяни займаються для зміцнення власного здоров я та змістовного проведення відпочинку. По-скільки професійний спорт є одним із важливих сегментів, що формує престиж держави на міжнародній арені, то ним опікуються органи управління на загальнодержавному і регіональному рівні, які потребують теоретичних напрацювань та соціологічних даних. Як правило, організацію занять населення фізичною культурою і спортом беруть під опіку в першу чергу органи місцевого самоврядування. Зрештою, у великих містах, що є засновниками або співзасновниками професійних спортивних колективів (футбольний клуб «Львів», баскетбольний клуб «Миколаїв» тощо) підтримка таких клубів, а також окремих визначних спортсменів здійснюється за рахунок спеціально акумульованих коштів із фондів місцевого бюджету та за рахунок спонсорської допомоги.

Аналіз останніх досліджень і публікацій. Необхідно враховувати, що фізична культура і спорт потребує теоретичного осмислення та методологічної підтримки. Проблему феномену фізичної культури та спорту як соціального, правового, економічного, культурного явища досліджує значне число вітчизняних і закордонних науковців, які у своїх трактуваннях його понятійної сутності виходять із концептуальних позицій, що притаманні відповідній науковій галузі до якої вони належать. Зокрема, трактування «фізичної 
культури і спорту» ми маємо розглядати виходячи із контексту яким чином йде вивчення даного сегменту людської діяльності в рамках різних наукових дисциплін, а також науковими школами тощо. Особливої актуальності набувають дослідження змісту, форм, методів, принципів, механізмів державного управління на регіональному рівні в світлі проблем окреслених у концепції «Загальнодержавної цільової соціальної програми розвитку фізичної культури і спорту» [10], та виходячи 3 мети надання більш широких повноважень місцевим органам влади і фізкультурно-спортивним товариствам тощо.

У нашій країні ефективним способом по вирішенню значимих проблем стало напрацювання цільових комплексних програм, що вимагають суттєвих фінансових витрат, концентрації зусиль різних міністерств і відомств. У цій частині соціально-економічної сфери за роки незалежності накопичено суттєве теоретичне осмислення i практичний досвід. Аналіз наукових публікацій 3. Бурик, I. Гасюка показує, що при розгляді даного виду управління послуговуються низкою базисних понять, які широко застосовуються у вітчизняній практиці: «програмно-цільове управління», «програмно-цільовий метод управління», «програмно-цільовий принцип управління», «програмно-цільовий підхід» тощо. Очевидно маємо підстави поділяти твердження І. Нікуліної, що сутністю програмно-цільового управління є намагання досягнути певного результату і мети, що здійснюється при допомозі реалізації цільових комплексних програм [14, с. 190]. Необхідно підкреслити, що всі види управлінських дій на програмно-цільовій основі, які охоплюють планування, прогнозування, організацію, координацію, використовують єдину методологію, яка отримала назву програмно-цільового підходу або програмно-цільового методу. Вітчизняні науковці опрацьовуючи теорію соціального управління бачить в управлінні функцію організованих систем, що мають на меті гарантувати стабільність структури в режимі іiі функціонування та втілити програмні завдання і прагнення маючи на увазі досягнення наміченої мети.

Формування цілей статті (постановка завдання). Назріла необхідність:

- визначитися із суб'єктністю законотворчої ініціативи; 
- осмислити відмову від парадигми самодостатності законодавчої діяльності;

- визначитися 3 підходами до теоретичних засад соціологічних досліджень становища фізичної культури і спорту;

- усвідомити необхідність і важливість запровадження контролю щодо законодавчої роботи владних суб'єктів 3 боку громадськості тощо.

Виклад основного матеріалу дослідження. Наразі здійснюються невідкладні кроки спрямовані на напрацювання системної роботи 3 метою організувати послідовну законотворчу роботу, яка при дотриманні всіх відповідних процедур, що забезпечить бажаний рівень ефективності такого роду діяльності, в тому числі гарантуватиме стійкість від зміни політичної кон'юнктури. В основу цього підходу потрібно закласти низку принципових положень. Динаміка суспільних відносин і окремих їх сфер не можлива без прийняття і реалізації визначеного кола законодавчих актів та норм, тому державне управління є феноменом, що має складну й універсальну суспільну структуру. Не підлягає сумніву те, що управління може бути притаманним для динамічних систем соціального і несоціального спрямування, одним з іманентних атрибутів яких виступає самоуправління, інакше кажучи, потенційна здатність системи впорядковуватися.

Управлінські технології державного управління фізичною культурою і спортом взаємопов'язані й опираються на фундаментальні засади, що виступають методологічним базисом всього цього процесу. Важливу роль науковці при напрацюванні теоретичних засад надають практичному підгрунтю своїх концептуальних положень. В цьому контексті важливе місце набувають статистичні методи дослідження. «Якщо у наукових дослідженнях середнє арифметичне значення і показник варіативності використовуються незалежно, то символи, якими вони позначаються, не мають такого «принципового» значення, адже вони не впливають на кінцевий результат аналізу, хоча очевидно, що вони повинні бути уніфікованими і позначатися загальноприйнятими «Х» та «о̛». Це обумовлено тим, що статистичні показники, як літери в абетці, дають можливість науковцям пра- 
вильно «читати» експериментальний матеріал, а отже, об'єктивно сприймати результати дослідження. Зовсім інша ситуація виникає у випадку, коли аналізується співвідношення між середнім значенням і показником варіативності ( $\mathrm{X} \pm-$ показник варіативності). У цьому разі має принципове значення, який саме показник варіативності використовується, адже між «о̛» $\mathrm{i}$ «m» існує суттєва відмінність. Символом «т»» в описовій (прикладній) статистиці позначається показник, який має назву «помилка репрезентативності» (або статистична помилка). Він характеризує наскільки експериментальна вибірка представляє (репрезентує) генеральну сукупність. Тобто помилка репрезентативності характеризує відхилення вибіркового показника від його генерального параметра. Помилки репрезентативності притаманні тільки вибірковим спостереженням. Вони виникають у результаті того, що вибіркова сукупність не повністю відтворює генеральну» [18, с. 84]. Загальновідомо, що головною та найсерйознішою причиною прогалин у фізкультурному русі $\epsilon$ нераціональний спосіб життя, неоптимальне використання сьогоднішніх досягнень науки про людину, про її резерви, психофізіологічні, фізичні можливості. Результати статистичних досліджень здоров'я людини та чинників, що впливають на його стан, показують, що здоров'я людини залежить від:

- стану медицини - на 10\%;

- впливу екологічних чинників - на 20-25\%;

- генетичних чинників - на 20\%;

- умов і способу життя - на 50\% [15, с. 41].

Якщо пильно придивитися до семантики змісту терміну «управління», то вона містить одну зі знакових ознак - мету, а також гармонізацію процесів, що спрямовані на ії досягнення. Така гармонізація може бути набута в ході впровадження структурно-змістовного ранжування при постановці завдань і мети, в процесі впорядкування методів і засобів управлінських рішень виходячи з часово-просторових характеристик, визначення потрібного для цього ресурсного забезпечення. Спираючись на вищезазначене можемо констатувати, що планування є провідним складником при управлінні процесом розвитку фізичної культури та спорту в регіонах, воно покликане 
бути гармонійним, тобто узгоджуватися із динамікою розвитку даної сфери. Стратегічне планування потрібне і надзвичайно важливе в процесі здійснення заходів спрямованих на покращення ефективності державного управління фізичною культурою та спортом на рівні регіону. Завдячуючи йому, вдається досягти комплексної та системної координації функціонування всієї системи державного управління, ефективність якої досягається завдяки передачі певних повноважень нижчим управлінським ланкам.

Вся сукупність методів, завдань, заходів та засобів спрямованих на досягнення відповідного розвитку галузі фізичної культури та спорту в середньостроковій і довгостроковій перспективі, становлять збалансовану науково обгрунтовану систему і стратегію розвитку сфери фізичної культури і спорту. Дану стратегію можна реалізувати завдяки залученню програмно-цільових підходів, що виступають одним з елементів стратегічного планування. Тому низка дослідників, серед них І. Гасюк, сформулювали бачення програмноцільового підходу який є механізмом державного управління розвитком фізичної культури та спорту, що при використанні відповідних управлінських технологій (моніторинг, оцінювання, прогнозування, планування, програмування та ін.), засобів і методів може забезпечити досягнення мети та вирішити програмні завдання дотримуючись принципів і вимог до предметної сфери його застосування [3]. Науковці та управлінці послуговуючись програмно-цільовим підходом в якості інструментальної складової, зачасту використовують програмно-цільовий метод, що дозволяє забезпечити координацію дій при управлінні між об'єктом та суб'єктом, регламентувати способи як задіяти засоби управління в процесі реалізації різноманітних управлінських технологій спрямованих на реалізацію програмних цілей і досягнення поставленої в процесі управління мети [4].

Більш глибокому розумінню сутності програмно-цільового управління може сприяти знання про існуючі класифікації цільових комплексних програм. За характером мети, яку переслідують управлінці при виконанні програм і впливу результатів їх реалізації на розвиток народного господарства, вони поділяються на ключові кластери: виробничі; економічні; науково-технічні; соціальні 
програми, безпосередньо розраховані на задоволення потреб населення, забезпечення найбільш сприятливих умов, які сприяють соціальному розвитку трудящих; ті, що впливають на розвиток культури, освіти, медичного забезпечення, побутового та інших видів обслуговування тощо. Комплексні програми також доцільно розділити наступним чином: функціональні програми; програми цільового розвитку; будівельні програми; організаційні програми. I, зрештою, ще одним важливим фактором, який впливає на формування систем управління комплексними програмами $є$ період їх реалізації: безперервні; довгострокові; поточні.

Розробка програм в яких використано програмно-цільовий метод провадиться за дотримання певної послідовності:

1. Формується перелік найбільш важливих проблем та визначається ключова проблема цільової програми.

2. Формулюється вихідне завдання на розробку програми з метою вирішення певної проблеми, де відображено мету програми, ліміт задіяних ресурсів, безпосередні учасники і термін дії програми. На цьому етапі визначаються параметри, що характеризують мету програми і формуються заходи покликані реалізувати їі відповідно до окремо визначених періодів. Інакше кажучи, генеральну мету розбивають на складові чинники.

3. Прописується перелік завдань та комплексні заходи спрямовані на реалізацію програми. Послідовність ключових дій покликаних виконати програму визначається, зважаючи на побудовану ієрархію цілей. Для реалізації кожного завдання напрацьовуються послідовні етапи їх виконання.

4. Здійснюється прогнозований розрахунок найважливіших показників та ресурсних потреб, щоб забезпечити реалізацію програми. Закладається показник матеріального, трудового, фінансового ресурсу, необхідного в процесі втілення у життя програми. Цей етап важливий для розрахунку показника наскільки ефективною може бути реалізація програми.

5. На завершальному етапі формування програмних документів, узгодження, за потреби, затвердження програми планування потрібно здійснювати дотримуючись чітко визначених принципів і 
правил іiї формування. Важливе місце необхідно відвести обгрунтуванню і організації напрацювання планових документів. Ключове місце в цьому процесі посідають принципи науковості, соціальної спрямованості, пропорційності та збалансованості, пріоритетності, узгодженості короткострокових, середньострокових та довгострокових цілей [16].

Характерно, що програмно-цільовий метод управління використовувався в централізовано керованій радянській економіці в тій же мірі, що і в ринковій економіці капіталістичних країн в силу його відносної інваріантності стосовно типу і природи соціально-економічних систем. До особливостей цільової програми як самостійного об'єкту планування та управління, в першу чергу, відносять ії орієнтацію на конкретну мету, що передбачає значний зсув, досягнення певного нового якісного стану. По-друге, цільова програма, зазвичай, є довгостроковою або середньостроковою і носить кінцевий за часом характер. По-третє, заходи, що становлять сутність програми, утворюють єдиний комплекс. По-четверте, програмні заходи, зазвичай, носять міжвідомчий характер і дуже часто відносяться до різних галузей, отже, їх узгодження і координація практично не може бути здійснена на основі роз'єднаних лінійно-функціональних структур управління.

Аналізуючи численні наукові праці ми прийшли до переконання, що методичною основою програмно-цільового підходу в якості механізму державного управління розвитком фізичної культури та спорту становлять предметна сфера його використання, можливості даного підходу стосовно вирішення виникаючих проблем, передумови щодо його впровадження у повсякденну практику управлінської діяльності, підходи до його застосування, методи та засоби, які сприяють вирішенню поставлених завдань і у досягненні визначеної мети, допомагають впорядкувати науково-категорійний апарат тощо.

Стратегічне планування і реалізація розробленої стратегії пов'язані з низкою важливих підвалин, що значною мірою обумовлюють ефективність дій управлінця та ефект від безпосередньої реалізації заходів, що покликані досягнути визначеної у них мети. 
Успішно впоратися з цілим спектром питань, що зазвичай виникають у результаті проведення грунтовного аналізу динаміки сутності правових засад і наслідків реалізації регіональних та місцевих програм, які скеровані на розвиток фізичної культури та спорту, удосконалення методологічних засад і підходів до стратегічного планування даної сфери людської діяльності. У вітчизняній науці достатньо мало праць, де висвітлено зміст етапів та методологічні особливості при стратегічному плануванні процесів галузі фізичної культури та спорту на рівні регіонів. Дослідники умовно виділяють два періоди регіонального стратегічного планування розвитку фізичної культури та спорту. Перший пов'язують із зародженням та становленням регіонального перспективного планування розвитку фізичної культури та спорту в нових соціально-економічних умовах (його датують 1992-2000рр.). У цей час відбулося прийняття Закону України «Про фізичну культуру і спорт» датованого 24 грудня 1993 року, який заклав нормативно-правові підвалини стратегічного планування розвитку галузі. Започаткували другий етап прийняті Закони України «Про державне прогнозування та розроблення програм економічного і соціального розвитку України» (2000р.) [6], «Про державні цільові програми» (2004р.) [7].

На сьогодні напрацьовано і розроблено різноманітні форми i планові показники галузі державного управління фізичною культурою та спортом. Значного поширення набуло директивне, стратегічне й індикативне планування. Говорячи стосовно стратегічного планування сферою фізичної культури та спорту на регіональному рівні, є підстави бачити його цілеспрямованим та організованим процесом розробки першочергових, обгрунтованих економічно і соціально заходів, що мають бути досягнуті в середньостроковій чи довгостроковій перспективі. Стратегічне планування процесів розвитку фізичної культури та спорту в регіонах нашої держави повинно опиратися на чіткі нормативно-правові підходи, визначати конкретних виконавців на кожному управлінському рівні (державному, регіональному, місцевому) [19]. На центральному (загальнодержавному) проводиться напрацювання нормативно-правових підстав для стратегічних змін в розгортанні фізкультурно-спортивного руху в 
регіонах. В їхню основу повинні бути покладені: Конституція України, Закон України «Про фізичну культуру та спорт», Закон України «Про державне прогнозування та розроблення програм економічного і соціального розвитку», Закон України «Про стимулювання розвитку регіонів» [9], «Закон України про місцеве самоврядування», «Закон України про місцеві державні адміністрації» [8] та інше.

Основні напрями розробки і формування організаційної основи управління динамікою фізичної культури і спорту містяться в оптимізації системи спортивних і фізкультурних заходів; вдосконаленні взаємодії суб'єктів фізичної культури і спорту; розробці ключових параметрів рухової активності для населення різної вікової категорії і соціальної приналежності; напрацюванні системи фізичного виховання і вдосконалення людини на різних етапах іiі життя, в першу чергу, підростаючого покоління. Необхідно зближувати фізичну культуру і спорт з іншими сферами людської діяльності, що державою визначено в якості одного із важливих напрямків подальшого підйому масовості та закладено соціально-економічні підвалини іiі функціонування і розвитку. Особливої актуальності набувають кроки по розв'язанню цього питання за умов подальшого становлення і розвитку ринкової економіки. В цьому контексті важливе місце відводиться регіонам та їхнім органам управління, зміст діяльності яких має полягати в намаганні забезпечити розвиток нових суспільних відносин, в тому числі у сфері фізичної культури і спорту [11, c. 156$]$.

Необхідно зважати на ту обставину, що управлінські дії здійснюються в системах, які складають мережу причинно-наслідкових залежностей, що здатні в межах цієї основної якості переходити 3 одного стану в інший. Дані процеси забезпечують стабільність та динаміку системи, обумовлюють зберігання їі якісних показників, підтримують постійну взаємодію із зовнішнім середовищем. Маємо взяти до уваги, що дані системи можуть функціонувати за умови безперервної зміни внутрішнього і зовнішнього середовища, тому завдання управлінських структур повинно полягати в тому, аби вірно та своєчасно відреагувати на такі зміни. Це може бути забезпечено вчасним налаштуванням функціональної і організаційної 
структури даної системи у відповідності притаманним для неї закономірностям та тенденціям [5, с. 21].

Нас не може не цікавити як тлумачити поняття «управління» яким послуговуються при характеристиці особливої управлінської дії в різноманітних сферах суспільної життєдіяльності, зокрема при забезпеченні державного управління фізичною культурою і спортом України. Адже фізична культура і спорт були і залишаються невід’ємною складовою соціального буття спільноти, атрибутом iii нематеріального виробництва. При цьому, цілком правомірним i доцільним послуговуватися поняттям «управління» щодо фізичної культури і спорту як окремої галузі.

У загальному вигляді під управлінням розуміють спрямоване, усвідомлене переведення якогось об'єкта (завжди виступає складною системою) 3 первинного стану до іншого. Тому не випадково відбулося виділення управління в окремий кластер людського знання і в науку вже на кінець XIX сторіччя. Його наукове підгрунтя наразі становить ввесь накопичений досвід і навички щодо управління, котрі були сформовані в процесі практичного виконання управлінських дій. Воно представлене в якості різноманітних теоретичних розробок і концепцій, основу яких складають досліджені закономірності та обгрунтовані закони, підходи, засади, функціональні прояви, форми та методи цілеспрямованих дій індивідів, які скеровані з метою реалізації управлінської функції. Зачасту у повсякденні доводиться мати справу з твердженням, що управління $\epsilon$ мистецтвом, яке пов'язують із вмінням управлінців ефективно послуговуватися накопиченими знаннями і напрацьованим досвідом в ході практичної управлінської діяльності. Очевидно такий підхід базується на підставі наступних чинників: об'єднання і організація фізкультурно-спортивного спрямування є складними відкритими соціальними (соціально-технічними) системами, діяльність яких залежить від різноманітних чинників пов'язаними із зовнішнім та внутрішнім середовищем. Окрім опори на досягнення науки при здійсненні управлінських дій, менеджер зазвичай, використовує в конкретних випадках й накопичений досвід та набуті знання. Тому наявні фахівці фізкультурно-спортивних організацій і їх кваліфіка- 
ція є важливою складовою, що забезпечує ефективність системи. Державним службовцям притаманна напрацьована власна система преференцій і мотивації діяльності. Зважаючи на цю обставину, управлінський процес трактують в якості сукупності дій, де наукові підходи та досвід управлінця виступає мистецтвом, коли потрібне перманентне накопичення знань і теоретичне їх напрацювання, а також постійний розвиток і вдосконалення особистих менеджерських якостей фахівця, його здатність послуговуватися набутими навичками та знаннями, коли виникають неординарні ситуації в процесі практичного виконання покладених на нього обов'язків. Метою має бути максимальне забезпечення тісної взаємодії всього управлінського персоналу та створення умов, що сприяли би вичерпній реалізації потенціальних можливостей усіх працюючих. В свою чергу, поділ праці обумовив те, що управління виділилося в особливу функцію, яка $є$ принципово відмінною за призначенням і змістом від звичної для нас виробничої функції. Як специфічний вид життєдіяльності управління покликане реалізуватися за допомогою здійснення послідовних управлінських дій, які класифікуються як «функції» управління. Звісно, що кожна управлінська функція має розглядатися в якості самостійного процесу. Тому, маємо враховувати, що функції управління - це низка окремих, зазвичай формально не пов'язаних дій менеджера, які складаються в цілісний процес 3 метою інтегрувати всю його діяльність. У цій ситуації при трактуванні управління як цілеспрямованого процесу робиться акцент на тій обставині, що виконання певних управлінських функцій (коли розглядаємо кожен окремий випадок) виступає як процес, що можна змістовно пов'язати з іншими управлінськими функціями. Тобто $є$ підстави твердити - «мікропроцеси» в ході реалізації управлінських функцій розглядаються в якості розгорнутого управлінського «макропроцесу» [17].

Загальний контекст поняття «державне управління» можемо екстраполювати стосовно всіх трьох владних гілок - законодавчої, виконавчої і судової, а у вузькому трактуванні - виключно виконавчої. Поняття державного управління як самостійна форма діяльності держави набуло найбільшого поширення, яке проявляється як 
організуюча, виконавчо-розпорядча функція, що характеризує особливу групу державних органів у процесі безпосередньої реалізації функцій і завдань представників держави в ході щоденного і безпосереднього керівництва економікою, соціально-культурною і адміністративно-політичною сферою країни. Значна частина вітчизняних дослідників поділяє думку стосовно організуючого, виконавчо-розпорядчого характеру управлінської діяльності, яка спрямовується на реалізацію функцій і завдань притаманних державі.

Енциклопедичні видання, спеціальна література та у дисертаційних роботах поняття «управління» загалом розглядають як один 3 елементів або функцію організованих систем різного походження (технічного, біологічного, соціального) [2]. Іноземні науковці визначають багатозначність терміну «управління». У загальному контексті ними розподілено поняття «управління» розділено на два кластери: управління людськими ресурсами і управління персоналом. Управління людськими ресурсами має відмінні особливості від управління персоналом і полягає в прийнятті співробітниками організації стратегічних завдань, що характеризує прагнення повною мірою залучити працівників у процеси по реалізації мети організації і бажання здійснити власний внесок у кінцевий результат, продемонструвати переваги конкретної організації, а також поєднання інтересів організації із запитами працівників. В свою чергу, управління персоналом більшою мірою пов'язують із адміністративним підходом при виконанні обов'язків працівниками. Потрібно пам'ятати, що управління людськими ресурсами може перебувати у протиріччі $з$ управлінням персоналом. Враховуючи дану обставину маємо підстави твердити, що управління людськими ресурсами покликане вирішувати стратегічні завдання, тоді як управління персоналом переслідує тактичну мету [13, с. 7]. Маємо також врахувати, що управління представляє собою складний і універсальний суспільний феномен. Очевидно найбільш широко його зміст розкриває філософська наука, яка трактує управління як функцію організованих систем, що дозволяє їм зберегти свою структуру, постійно підтримувати режим діяльності, здійснювати реалізацію власних програм, в кінцевому результаті досягати поставленої мети. 3 філософського 
пункту бачення, управління є необхідною і невід'ємною функцією суспільного життя. Його метою виступає організація спільної діяльності людей, чи їх окремих груп та організацій, забезпечення координації взаємодії між ними, а його суттю - здійснення керуючого впливу на певні об'єкти [12, с. 12].

Висновки. На наше переконання комплексність, системність, цілісність управління фізичною культурою і спортом достатньою мірою забезпечується розвитком теоретичних і методологічних обгрунтувань у сучасному суспільстві. В якості органічного поєднання програмного і цільового підходів нами розглянуто програмно-цільове управління, інтеграція яких значною мірою посилює обгрунтування проблеми, лягає в основу подальшої розробки програмних дій і заходів задля осягнення мети, сприяє концентрації ресурсів для отримання очікуваних результатів, узгодження термінів, виконавців, функцій і методів управлінських дій, а також прискорює науково-експериментальні процеси i, загалом, знижує невизначеність майбутнього. Організація управління на програмно-цільових засадах сприяє забезпеченню пріоритету народногосподарських інтересів, гальмує відомчий та містечковий сепаратизм, дозволяє зорієнтувати виконавців оператися на комплексний підхід при використанні ресурсної бази із метою досягнути максимальних кінцевих результатів.

Стаття надійшла до редакціi: 11.02.2019

THEORETICAL APPROACHES IN THE PROCESS OF THE REALIZATION OF PUBLIC ADMINISTRATION BY PHYSICAL CULTURE AND SPORTS

Sergyi Nikitenko, $\mathrm{PhD}$ of History, Kherson state agrarian University, Kherson, Ukraine

Based on the analysis of existing scientific approaches, the article explores the essence of the mechanisms of state management of physical training and sport in Ukraine. Particularly, the contemporary scientific 
constructs are considered to the definitions of "physical training and sport" and "mechanism of state management", "program and targetoriented management", "program and target-oriented method of management", "program and target-oriented principle of management" and "program and target-oriented approach". As a specific type of life's activity, the management is appealed to be realized by means of implementation of consistent management actions, which are classified as "functions" of management.

In the article it is urgent that often in everyday life has to deal with the assertion that management is an art that is associated with the ability of managers to effectively use the accumulated knowledge and experience gained during practical management activities. Obviously, such an approach is based on the following factors: the association and organization of physical culture and sport direction are complex open social (social-technical) systems, whose activities depend on various factors related to the external and internal environment. In addition to relying on the achievement of science in the conduct of managerial actions, the manager usually uses in specific cases and the accumulated experience and acquired knowledge. Therefore, existing specialists of sports and sports organizations and their qualifications are an important component that ensures the effectiveness of the system. Civil servants have their own system of preferences and motivations of activity. Given this circumstance, the management process is interpreted as a set of actions in which the scientific approaches and experience of the manager is an art when a permanent accumulation of knowledge and theoretical work is required, as well as the constant development and improvement of the personal managerial qualities of a specialist, his ability to use his acquired skills and knowledge, when there are extraordinary situations in the process of practical implementation of the duties assigned to him. The author emphasizes that the goal should be to ensure the maximum interaction of all management personnel and create conditions conducive to the full implementation of the potential of all employees. In turn, the division of labor stipulates that the management has been allocated to a special function, which is fundamentally different in purpose and content from the usual production function for us. 
The article draws attention to the necessity to define the essence of a newish specific mechanism of state management, which arises as a result of the process of decentralization of power in Ukraine. Based on the conducted research, the conclusions on understanding of the essence of the mechanisms of state management of physical training and sport in Ukraine were made.

Keywords: physical training and sport, mechanisms of state management.

\section{Received: 11.02.2019}

\section{References}

1. Buryk, Z.M. (2008). Monitorynh u prohramno-tsilovomu upravlinni rehionalnym rozvytkom [Monitoring in programmatic management of regional development resource] Demokratychne vriaduvannia - Democratic Governance 1. Retrieved from http://www.nbuv.gov.ua/e-journals/DeVr/200801/zmist.html [in Ukrainian]

2. Vavrenyuk, S.A. (2015). Mekhanizmy derzhavnoho upravlinnia rozvytkom fizychnoi kultury i sportu u vyshchykh navchalnykh zakladakh Ukrainy [Mechanisms of Public Administration for the Development of Physical Culture and Sports in Higher Educational Institutions of Ukraine]. Candidate's thesis. Kharkiv. [in Ukrainian]

3. Gasyuk, I.L. (2011). Program-target approach - a scientific category of the theory of state administration for the development of physical culture and sports / I.L. Gasyuk // Economy and the state. - No. 4 - P. 126-128.

4. Gasyuk, I.L. (2011). Program-target approach as a mechanism of state management of development of physical culture and sports / I.L. Gasyuk // Investments: practice and experience. No. 5- S. 95-100. [in English]

5. Melnik, A.F. Obolensky, O.Y. Vasina A.Y. (2003). [Public administration: Teaching. manual]. K. Knowledge-Press. [in English]

6. Zakon Ukrainy «Pro derzhavne prohnozuvannia ta rozroblennia prohram ekonomichnoho i sotsialnoho rozvytku Ukrainy» [The Law of Ukraine «On State Forecasting and Development of Programs of Economic and Social Development of Ukraine»] (n.d.). zakon.rada.gov.ua. Retrieved from http:// zakon.rada.gov.ua/laws/show/1602-14 [in Ukrainian] 
7. Zakon Ukrainy «Pro derzhavni tsilovi prohramy» [The Law of Ukraine «On State Target Programs»] (n.d.). zakon.rada.gov.ua. Retrieved from http:// zakon.rada.gov.ua/laws/show/1621-15 [in Ukrainian]

8. Zakon Ukrainy «Pro mistsevi derzhavni administratsii» [The Law of Ukraine «On Local State Administrations»]. (n.d.). zakon.rada.gov.ua. Retrieved from http://zakon.rada.gov.ua/go/586-14[in Ukrainian]

9. Zakon Ukrainy «Pro stymuliuvannia rozvytku rehioniv» [The Law of Ukraine «On Stimulating the Development of Regions»]. (n.d.). zakon.rada.gov. ua. Retrieved from: http://zakon.rada.gov.ua/go/2850-15 [in Ukrainian]

10. The Concept of the National Target Social Program for the Development of Physical Culture and Sports for 2012-2016 [Electronic Resource]. - Retrieved from: http://www.kmu.gov.ua. / ua / npas / 248719473 [in Ukrainian]

11. Kudlata, K.V. (2013). State Administration of Physical Culture and Sports at the Regional Level: Concept and Essence / K.V. Kudlata // Investments: practice and experience. Governance. - 2013. - No. 23. [in Ukrainian]

12. Malinovsky, V.Ya. (2000). Public Administration: Textbook, - Lutsk: Rev. away "Tower" Vol. state un-th them Lesia Ukrainka. [in Ukrainian]

13. Mozolev, O.M. (2016). Management of the development of education in the field of physical culture and sports from the Polish experience / O.M. Mozolev // Zbiór artykułów naukowych. Conferences in Miedzynarodowej Naukowo-Praktycznej "Pedagogy. Badania podstawowe i stosowane: wyzwania i wyniki". - Warszawa: Wydawca: Sp. z o.o. Diamond trading tour, 2016. [in Poland]

14. Nikulina, I.E. (2006). Modern features of software-target management of organizations / I.E. Nikulina, D.V. Lukov, B.S. Mozgolin // Izvestiya of Tomsk Polytechnic University / Socio-economic and humanities. - T. 309. No. 3. [in Russian].

15. Obozna O.M. Rozvytok fizychnoi kultury i sportu yak vazhlyvyi napriam derzhavnoi polityky Ukrainy shchodo zabezpechennia zdorovia hromadian [Development of physical culture and sport as an important direction of the state policy of Ukraine in ensuring the health of citizens] Retrieved from: http://academy.gov.ua/ej/ej20/PDF/8.pdf [in Ukrainian].

16. Orlov M.M. Principles of Public Administration in Ukraine: Transformation to Modern Conditions / M.M. Orlov [Electronic resource]. Retrieved from https://sworld.com.ua/konferger1/8.pdf [in Ukrainian]

17. Parkhomenko-Kutsevil, O. (2015). Pryntsypy formuvannia kadrovoi bezpeky systemy derzhavnoho upravlinnia: teoretychni zasady [Principles of Personnel Security Development in the System of Public Administration: 
Theoretical Foundations]. Aktualni problemy derzhavnoho upravlinnia-Current Problems of Public Administration. 2 (62),17-20. [in Ukrainian]

18. Sutula V. Features of the application of methods of mathematical statistics in the scientific research of the field of physical culture and sports / V. Sutula // The theory and methods of physical education and sport. $-2014-\# 1$. [in Ukrainian]

19. Ukaz Prezydenta Ukrainy «Pro kontseptsiiu derzhavnoi rehionalnoi polityky» [«Decree of the President of Ukraine on the concept of state regional policy»]. (n.d.). zakon.rada.gov.ua. Retrieved from https://zakon4.rada.gov.ua/ laws/show/341/2001 [in Ukrainian]

\section{Відомості про авторів / Information about the Authors}

Нікітенко Сергій: ДВНЗ Херсонський державний аграрний університет: вул. Стрітенська, 23, м. Херсон, 73006, Україна.

Sergyi Nikitenko: Kherson State Agrarian University: st. Sretenskaya, 23, Kherson, 73006, Ukraine.

\section{E-mail: khersonshina@ukr.net}

